\title{
Resources of the Region in the Function of Agriculture and Rural Development of Montenegro
}

\author{
Sreten JELIĆ( ${ }^{(*)}$, Mersida JANDRIĆ ${ }^{11}$, Dragić ŽIVKOVIĆ ${ }^{1)}$, Zoran MILOVANČEVIĆ ${ }^{1)}$ \\ 1) Faculty of Agriculture, University of Belgrade, 6 Nemanjina St., 11000 Belgrade, Serbia. *Correspond- \\ ing author, e-mail: sjelic@agrif.bg.ac.rs
}

Bulletin UASVM Horticulture 71(2) / 2014

Print ISSN 1843-5254, Electronic ISSN 1843-5394

DOI:10.15835/buasvmcn-hort:10443

\begin{abstract}
In very short time big changes occurred in the agrarian structure, the structure of the population, territorial and socio-economical deployment. According to that, there is an obvious discontinuity in the development of rural areas. Pointing out the resources of the region during transformation and rapid development of agriculture, rural development and development of rural regions. The largest part of the development potential based on resource utilization is precisely located in the northern region of Montenegro. The basic method used in this paper is descriptive statistics applied to the collection of relevant data resources of the region, document analysis, comparison and synthesis. The significant changes in socio-demographics appeared, an increasing part of the elders and the decreasing of the youth, and decreasing the part of the agricultural population. The main leading factors of the development of agriculture and rural development are the family farms in the region, which is about 26.000 and the resources of land, livestock, and labor. The specificity of the region is reflected in the changing structure of the agricultural population, socio-economic, demographic, territorial distribution of the population, and migration. The significant differences in the development of agriculture and rural development in the region are also present. Resources are not fully utilized in order to reduce the differences in the development of the region and to accelerate the development of less developed areas. Also, the regional development of the areas is needed for measures and program of balanced development of local self-government.
\end{abstract}

Keywords: agriculture, Montenegro, region, resources, rural development.

\section{INTRODUCTION}

Rural development is a complex social phenomenon that takes into account resources affecting development. Researches have been dealing with theoretical and practical changes in the concept of rural development, causing a considerable interest in the study of rural areas (Chambers, 1983; Ploeg Van der, 1994; Hoppers, 2002; Salvadori, 2003). Resources are seen as a precondition for development and a source of a comparative advantage in rural areas.

The present paper considers some major resources of the North region of Montenegro in the development of agriculture and rural development. In a very short time major changes in the agrarian structure have occurred (Kalezic, 1997), economic, professional, population structure, territorial and socio-economic deployment (Sarovic, 2012a). The transition process of the Montenegrin economy took place also in the process of agriculture. When comparing Montenegro to other countries, it is one of those economies that were relatively slower in the reform process, and in that context also in the process of privatization.

Stojanov (1997) points out that rural areas and agriculture have a certain social and economic potential, which is the starting point in the process of rebuilding rural areas. The specificity of Montenegrin agriculture are small family farms, fragmented and parcelled property with low productivity, ultimately resulting in the relatively low competitiveness of most agricultural commodities. Montenegrin agriculture has its advantages, which are reflected in the preserved land resources and low use of chemical agents, which gives the opportunity for the development of organic farming. 
Agriculture plays an important role in the development of rural areas especially since it participates in the generation of income in rural areas of Montenegro and the Northern region and thus ensures the survival of the population in rural areas. However, its integration with the secondary and tertiary sectors is necessary, more efficient connectivity of agriculture and food industry, the development of the service sector in rural areas, and all other aspects which are necessary for the survival and prosperity of these areas, rural development and development of rural areas. Sarovic (2012a) in the research points to the revitalization of the village and the orientation of young people in Montenegro, which points out that the young population is the main driver of the development of rural restoration.

Raonic (2009) emphasizes that key characteristics of the changes are depopulation, deruralization and deagrarization. These changes have greatly contributed to the reduction of economic resources of the rural areas, which has resulted in significant impact on rural areas. Agriculture is still the oldest economic activity and the most important one for the survival of the rural population. It is particularly important in less developed rural regions of Montenegro that changes have an important role in agricultural and rural development, since the possibilities for development are not used in the right way. In the agriculture and rural development in Montenegro significant changes have occurred. They are primarily the result of the overall economic development. There is a discontinuity in the development of rural areas. It is necessary to reduce the existing differences and balance the regional development (Jelic, 2008a).

The aim of the paper is to point out the importance of the resources in the region during transformation and rapid development of agriculture, rural development and the development of rural regions. The largest part of the development potential based on resource utilization is precisely located in the northern region of Montenegro. Resources are underutilized, which creates a potential for improving agricultural production and raising the competitiveness of food production in the region.

\section{MATERIALS AND METHODS}

The subject of the present study is resources of Northern region of Montenegro in the context of development of agricultural, rural development and development of rural areas. The northern region comprises $52.8 \%$ of the total territory of Montenegro, and $28.68 \%$ of the total population. Total number of family farms in the region is around 26,000 , they own $67.78 \%$ of the available land, $74.70 \%$ of the total agricultural land used, $62.33 \%$ of livestock units in relation to the total number in Montenegro (Statistical Office of Montenegro-Monstat, 2011).

The basic method, applied in this paper, is descriptive statistics applied to the collection of relevant data, and then grouping them based on attributive, geographical, time and numerical characteristics. This method has been applied to monitoring the movement of the population by sex, age, type of settlement in municipalities of Montenegro regions, the tendency of land areas owned by family farms according to their use, structure of the land property and livestock fund.

The analysis of documents, the comparative method and synthesis were also used in the present study.

The study used secondary data of the Statistical Office of Montenegro (Census of the population, Census of Agriculture, Bulletins, Newsletters, Releases), the Regional Development Strategy of Montenegro, year 2010-2014, data of the Ministry of Economy and the Ministry of Agriculture and Rural Development and the available literature.

\section{RESULTS AND DISCUSSION}

Agriculture of the Northern region has an important role in the economy and rural development. However, this branch of economy for years has had a subordinate position which resulted in increased migration of rural population to the cities. When soil resources, social capital / human/, livestock fund, etc., are taken into account there are opportunities for the development of agriculture, rural development and opportunities for increased agricultural production. The most of actual resources and comparative advantages are in underdeveloped regions (The Regional Developenemt Strategy of Montenegro, 2011)

In the area of the Northern region of Montenegro, population is continuously decreasing. Due to the demographic drain, this is the rarest 
Tab. 1. Number of population by sex and type of settlement in the regions of municipalities and structures in Montenegro, year 2011

\begin{tabular}{lcccccccccc}
\hline Region & $\begin{array}{c}\text { Number of } \\
\text { inhabitants }\end{array}$ & $\begin{array}{c}\text { Structure } \\
(\%)\end{array}$ & Men & $\%$ & Women & $\%$ & Urban & $\%$ & Other & $\%$ \\
\hline Montenegro & 620,029 & 100.0 & 306,236 & 49.40 & 313,793 & 50.60 & 392,020 & 63,23 & 228,009 & 36,77 \\
\hline $\begin{array}{l}\text { Northern } \\
\text { region }\end{array}$ & 177,840 & 28.68 & 89,576 & 14.45 & 88,264 & 14.23 & 71,673 & 40.30 & 106,167 & 59.70 \\
\hline Andrijevica & 5,071 & 0.82 & 2,614 & 0.42 & 2,457 & 0.40 & 1,048 & 20.67 & 4,023 & 79.33 \\
\hline Berane & 33,970 & 5.48 & 17,089 & 2.76 & 16,883 & 2.72 & 11,073 & 32.60 & 22,897 & 67.40 \\
\hline Bijelo Polje & 46,051 & 7.43 & 23,204 & 3.74 & 22,847 & 3.69 & 15,400 & 33.44 & 30,651 & 66.56 \\
\hline Kolašin & 8,380 & 1.35 & 4,229 & 0.68 & 4,151 & 0.67 & 2,725 & 32.52 & 5,655 & 67.47 \\
\hline Mojkovac & 8,622 & 1.39 & 4,352 & 0.70 & 4,270 & 0.69 & 3,590 & 41.64 & 5,032 & 58.36 \\
\hline Plav & 13,108 & 2.11 & 6,664 & 1.07 & 6,444 & 1.04 & 5,390 & 41.12 & 7,718 & 58.88 \\
\hline Pljevlja & 30,786 & 4.97 & 15,138 & 2.44 & 15,648 & 2.53 & 19,489 & 63.30 & 11,297 & 36.70 \\
\hline Plužine & 3,246 & 0.52 & 1,666 & 0.27 & 1,580 & 0.25 & 1,341 & 41.31 & 1,905 & 58.69 \\
\hline Rožaje & 22,964 & 3.70 & 11,776 & 1.90 & 11,188 & 1.80 & 9,422 & 41.03 & 13,542 & 58.97 \\
\hline Šavnik & 2,070 & 0.33 & 1,071 & 0.17 & 999 & 0.16 & 472 & 22.80 & 1,598 & 77.20 \\
\hline Žabljak & 3,569 & 0.58 & 1,773 & 0.28 & 1,796 & 0.30 & 1,723 & 48.28 & 1,846 & 51.72 \\
\hline
\end{tabular}

Source: Statistical Office of Montenegro, Monstat, 2012

populated region in the country. The significant changes in the socio-demographic structure of the population have occurred, an increasing share of the elderly and the decrease in the number of youth in the population, the decrease in the share of the agricultural population (Jelic and Jovanovic, 2003). The total population of the region is 177,840 or $28.68 \%$ of the total population of Montenegro. This is also the rarest populated region, the majority of people living in rural areas, while the majority of the urban population is only in the municipality of Pljevlja. The average population density in the North and North East region is 24.81 inhabitants per $\mathrm{km}^{2}$ (average for Montenegro is 47 inhabitants per $\mathrm{km}^{2}$ ). The population density is the lowest in the municipalities of Plužine and Šavnik, just 4 inhabitants per $\mathrm{km}^{2}$ and the highest in the municipality of Rožaje 53 inhabitants per $\mathrm{km}^{2}$.

The migratory movements in the region were long lasting and still on-going. The migration of the population is not specific to the Montenegrin society. All developed countries have gone through periods of mass exodus, especially youth, from villages and agriculture to cities and nonagricultural activities (Sarovic, 2012b). The most intense departure of population abroad occurred in the second half of the twentieth century, at a time of political and economic crisis, and to the neighbouring countries: mostly Serbia, European countries: Switzerland, Germany, France, and North America. The second type of migration is the relocation of the rural population to the cities, and emigration from the Northern region and the settlement of the central and southern regions of Montenegro. This movement expressed through the abandonment of the village reflects the changes in the economic and social structure of the population. The abandonment of the village is reflected on the change of non-agricultural population to the agricultural population, and at the same time the number of agricultural population and the population living in rural areas is decreasing.

In the North region, $40.30 \%$ of the population lives in urban areas and $59.70 \%$ of the total population of the region in other settlements. In the region, the concentration of population in cities and other settlements is lower, especially because the significant migration of population from rural to urban areas has occurred. Dominating sector of the economy in the specified region is agriculture, and in other settlements in the region, the majority of the population still lives in villages. The age structure of the population is unfavourable. In the 
Northern region, $18.2 \%$ of the population is under 14 years, $61.9 \%$ of the population is aged from 15-64 years and $15.8 \%$ of the population are over 65 years in relation to the total population of the region (Statistical Office of Montenegro-Monstat, 2011). The above socio- demographic structure of the population indicates the changes that have occurred, and are particularly pronounced on the territory of the eleven municipalities of this region (Jelic and Maric, 2008).

In regard to the average age of the population of Montenegro, the population in Andrijevica, Kolašin, Mojkovac, Pljevlja, Plužine, Šavnik and Žabljak is older than the average. In the municipalities of Berane, Bijelo Polje, Plav and Rožaje, the age of the population is below the average age of the population of Montenegro (Table 2).

The demographic problems in this region are due to several important factors: 1) lack of existing rural infrastructure; 2) migration of population from rural to urban areas; 3) unresolved issue of the social status of farmers (pension/retirement - social insurance); 4) unregulated market, or purchasing of agricultural products; 5) incentive measures of the state/government are not satisfactory, etc (Jelic, 2003).

\section{Characteristics of the soil and livestock fund in the region}

The Northern region covers an area of $7,304 \mathrm{~km} 2$, which represents about $52.9 \%$ of the territory of Montenegro. It is characterized by a great diversity of relief because on such small territory, high mountains over $2,000 \mathrm{~m}$ alternate with deep canyon valleys, high surfaces and complex river valleys with ravines. The relief is a constant category to which little or no impact can be exerted with measures such as contouring the contour lines, terracing, customizing by the way of exploitation of fragmented areas and steep slopes.

During the last ice age the greatest part of the area was covered by the ice sheet, so that the glacial erosion replaced karst erosion. Pulling of the glacier in the background created a big dent filled with water and turned into lake basins. In this way spacious surfaces were formed (Pivska and Jezerska) through deposition of materials stripped by glaciers, and where the material reconstructed the former bed of the glacier or river valley lake, basins were formed (Lake Plav).

The characteristic shape of the relief of the region, in addition to the high mountains and vast surfaces, are deep canyons formed by deepening of the riverbeds in the limestone surface. So some

Tab. 2. The number of average age of the population of the region according to municipalities in Montenegro, year 2011

\begin{tabular}{lccccc}
\hline \multirow{2}{*}{ Region/Municipalites } & \multicolumn{5}{c}{ The number of average age of the population } \\
\cline { 2 - 6 } & Total & Men & Women & Urban & Other \\
\hline Montenegro & 37.2 & 36.0 & 38.4 & 36.6 & 38.4 \\
\hline The Northern region & 38.9 & 37.8 & 40.1 & 37.1 & 40.2 \\
\hline Andrijevica & 39.9 & 39.2 & 40.6 & 38.1 & 40.3 \\
\hline Berane & 36.4 & 35.1 & 37.7 & 36.9 & 36.1 \\
\hline Bijelo Polje & 36.1 & 35.1 & 37.1 & 35.1 & 37.1 \\
\hline Kolašin & 40.1 & 38.7 & 41.5 & 37.6 & 41.3 \\
\hline Mojkovac & 38.4 & 37.0 & 39.7 & 37.4 & 39.1 \\
\hline Plav & 36.0 & 35.0 & 37.0 & 35.6 & 36.2 \\
\hline Pljevlja & 41.8 & 40.4 & 43.1 & 39.0 & 46.6 \\
\hline Plužine & 43.7 & 42.3 & 45.2 & 38.2 & 47.5 \\
\hline Rožaje & 31.7 & 31.1 & 32.2 & 32.2 & 31.3 \\
\hline Šavnik & 42.5 & 40.5 & 44.7 & 37.9 & 43.9 \\
\hline Žabljak & 41.9 & 41.0 & 42.8 & 40.5 & 43.3 \\
\hline
\end{tabular}

Source: Statistical Office of Montenegro, Monstat 2011 
Tab. 3. The number of family farms according to the used agricultural land in hectare in the Northern region of Montenegro in year 2010

\begin{tabular}{cccccccc}
\hline $\begin{array}{c}\text { Total } \\
\text { available } \\
\text { land (ha) }\end{array}$ & $\begin{array}{c}\text { Total utilized } \\
\text { agricultural } \\
\text { area } \\
\text { (ha) }\end{array}$ & $\begin{array}{c}\text { Utilized } \\
\text { family gardens and } \\
\text { land surrounding } \\
\text { farms (ha) }\end{array}$ & $\begin{array}{c}\text { Utilized } \\
\text { arable } \\
\text { land } \\
\text { (ha) }\end{array}$ & $\begin{array}{c}\text { Vineyards } \\
\text { (ha) }\end{array}$ & $\begin{array}{c}\text { Orchards } \\
\text { (ha) }\end{array}$ & $\begin{array}{c}\text { Nurseries } \\
\text { (ha) }\end{array}$ & $\begin{array}{c}\text { Permanent } \\
\text { meadowsand } \\
\text { pastures } \\
\text { (ha) }\end{array}$ \\
\hline $181,654.4$ & $158,959.1$ & $1,204.8$ & 1,558 & - & 466.2 & 487.2 & $155,242.9$ \\
\hline
\end{tabular}

Source: Monstat, Statistical Office of Montenegro 2011

canyons have depth of several tens of kilometres, and the best known as the Tara Canyon and Canyon Nevidio on the Komarnica River.

The hilly-basin area is allocated in the northeastern part of Montenegro, between the area of high mountains and valleys (the area around Lim, Ibar and Ćehotina). The average altitude of this area is about $800 \mathrm{~m}$, while the surrounding mountain ranges are over $1,500 \mathrm{~m}$, such as mountains Ljubišnja, Lisac, Crni vrh and Bjelasica. The rocks in this area form a thick layer of soil and because they retain water this is the most fertile area of the region.

The larger basins are: Andrijevica, Berane and Bijelo Polje in the valley of Lim river, Plavsko Gusinjska valley around Lake Plav and the largest Pljevlja valley in the valley of river Ćehotina.

The main characteristics of the soil types of the North region is their diversity, as well as factors that influence their formation are diverse (hydrological conditions, vegetation, rocky surface, expressed relief, and climate). The shallow soils mainly dominate with distinct discontinuity of arable land and cropping productive value. The largest part of arable farmland with relatively fertile land is located in narrow alluvial-diluvial valleys, mild to moderately steep slopes, terraces, karst valleys and flattened plateaus.

From the standpoint of crop production that requires large complexes of uniform land and application of large machinery, the relief restrictions and discontinuity of land which limits the application of agricultural technology and modern machinery, make the element of fertility of the soil and soil type insignificant and irrelevant. Soil quality can be perfect and ideal, but in small areas and inaccessible to machinery, productive capacity of the land is reduced, and therefore the production is economically unviable and unsustainable.
The diverse pedological cover of these regions is the result of the action of natural soil/ pedological factors and pedogenetic processes, but also of the influence of man and his lack of care and other activities (deforestation, pollution, changing agricultural construction land, strip mines) increasingly impoverished land cover.

The most important are agricultural land and land used in agriculture (fields, gardens, orchards, meadows, pastures). There is substantial potential in insufficient and irrational use of existing land surfaces, despite the limitation of this resource. In addition to the unfavourable structure of agricultural land, also present is its permanent reduction, especially of arable land. A significant part of the arable land, however, is not cultivated, but rather left wild.

Despite the fact that the land belongs to the category of resources that are renewed, under the influence of human factor, land as a resource becomes increasingly compromised. Destruction of arable farm land and their reduction primarily affects the population directly dependent on agriculture. Although there are different interpretations / definitions of rural areas OECD classification $^{1}$ is often used.

Family farms in the Northern region of Montenegro have in total 181,654.4ha of land available, 158,959.1 ha of agricultural land utilized, gardens and land surrounding farm houses occupy 2,404.8 ha, 1,558 ha of arable land, 466.2 ha of orchards, 487.2 ha of nurseries and permanent meadows and pastures 155,242.9 ha (Statistical Office of Montenegro-Monstat, 2011). (Table 3)

The most common are meadows and pastures, and as a consequence of climatic characteristics

1 Regions with over $50 \%$ of the population living in rural communities - predominantly rural regions; regions with 15 to $50 \%$ of the population living in rural communities - important rural regions or transitional regions; regions whith less than $15 \%$ of the population living in rural communities - mostly urban regions. 
of the region and the relief, arable land occupies merely $1.2 \%$. The regions have good prerequisites for increasing the volume of agricultural production as the share of meadows and pastures is considerable.

Natural and other conditions have influenced the differentiation of production orientation by regions, so that in this region the potato production is most present, followed by cabbage and other vegetables, milk, meat, and grains, fish farming and gathering forest fruits.

It should be pointed out that the land in this region is not protected from destruction and pollution, through conversion of agricultural land the roads are constructed, land fills, urban and rural areas, industrial and other facilities. Towns themselves are a major source of pollution with industrial and municipal waste which permanently impairs the quality of soil.

The forest land is also of great importance, it covers a large portion of the North and northeastern regions. Forests are represented in all eleven municipalities and cover an area of about 318,000 ha. Forest ecosystems have astabilizing role in the area in terms of preventing soil erosion and are the most important centres of biodiversity.

The livestock production has great economic importance in the Northern region of Montenegro. Exploitation of the agricultural land and natural conditions have influenced determinably the number of livestock, the intensity and structure of growing certain types of livestock in the region. The considerable presence of meadows and pastures which predominate in the total agricultural land in the region has caused that the cattle and sheep become the leading livestock species in the region. Modestarable land surfaces on the other hand, are preventing a greater presence of pigs. Thus, in the Northern region, the total of 78,633 heads of cattle, 157,443 sheep, 10,850 goats, 16,272 pigs and 155,656 poultry are reared on family farms (Statistical Office of Montenegro-Monstat, 2011).

In this region, about $65 \%$ of the total number of cattle in Montenegro is reared, although in recent years the number of cattle has declined as a result of depopulation and abandonment of villages.

In accordance with the available farmland, majority of cattleis in the municipalities of Bijelo Polje and Pljevlja. In these municipalities, 44.71\% of total number of cattle in the Northern region is located. The most of sheep are located in the municipalities of Berane, Bijelo Polje, Pljevlja and Plužine, or $62.38 \%$ of the total number in the region. In regard to pig and poultry production, decisive factor for production are the market capacities, so this production is located mostly near urban centres. Goats are reared sporadically in herds of sheep, mainly in the municipalities of Berane and Bijelo Polje. The majority of pigs and poultry are bred in Berane, Bijelo Polje and Pljevlja.

Available land resources are utilized in an optimal manner and provide great opportunities for development and increase livestock production.

The ownership structure of agricultural holdings in Montenegro is unfavourable especially because the share of farms with small land property is the highest; $45.08 \%$ of all farms have up to 1 ha of land, $5.34 \%$ of farms have 10 and more hectares (Statistical Office of Montenegro-Monstat, 2011). Due to the fragmentation of farms and numerous small parcels of lands, the productive capacityof farms is aggravated.

In order for the rural areas to become more significant producers of agricultural products and certain crops for which the conditions exist, it is necessary to take a series of measures in order to speed rural development and integrated rural development, such as construction of transportation and utility infrastructure, construction of facilities - plants on locations which provide daily labour migration, protection and enhancement of all agricultural land, establishment of cooperatives, agencies and services, more efficient use of invested funds and subsidies to revitalize agriculture in hilly and mountainous areas, as well as border areas, with comparative advantages in natural resources, better valorisation of agricultural householdsand social security ensured for farms in rural areas, economic and socio-cultural development of rural communities,rural cultural creativity and demographic renewal. Results of previous researches show a negative tendency - a migration of people from villages to towns, which causes a change in the population structure. This region has very important human and land resources, giving more opportunities for people to be engaged in agriculture, thus contributing to the development of rural areas and a higher standard of living (Jelic, 2008b). 


\section{CONCLUSIONS}

The most of the development potentials/ capacities are actually located in the Northern region, the territory of eleven municipalities inhabited by $28.68 \%$ of the total population and comprising $52.8 \%$ of the total territory of Montenegro. The specificity of the region is reflected in the changing structure of the agricultural population, socio-economic, demographic, territorial distribution of the population, migration.

The diversity of soil types in the region and the areas at the disposal of family farms made enables the farm members to engage in various branches of agricultural production. However, the limiting factor is primarily small property farms, decrease of agricultural land surfaces due to destruction and pollution. The livestock production, especially cattle breeding, has a significant role in the agriculture of this region.

In the Northern region, the resources for the development of agriculture and rural development are considerable, but not sufficiently exploited. Rural areas are characterized by a discontinuity in development. The process of industrialization has affected de-agrarization and de-ruralisation and reduction of the total agricultural population in the total population of the country and the region.

The presence of significant differences in the development of agriculture and rural development in the region is evident. Resources are not fully utilized in order to narrow the differences and accelerate the development of the less developed areas and regional development where the measures and program of balanced development of the municipalities are needed. Taking into account there sources available to the Northern region, rural areas have the potential for greater and faster development of agriculture, other economic activities and rural development.

\section{REFERENCES}

1. Chambers R (1983). Rural development: Putting the last first. Longman, London-Lagos-New York, $105 \mathrm{p}$.

2. Hoppers OC (2002). Indigenous knowledge and the integration of knowledge systems: Towards a philosophy of articulation. New African Books, South Africa, 93 p.

3. Jelic S (2008a). Agriculture changes and rural development in transition. Proc Multifunctional agriculture and rural development III (I):69-76.
4. Jelic S (2008b). Agriculture changes and rural development in transition. Proc Multifunctional agriculture and rural development III (I):70-73.

5. Jelic S, Maric N (2008). Agriculture resources of local communities and rural development. Proc Multifunctional agriculture and rural development III (I):293-300.

6. Jelic S, Jovanovic T (2003). Changes in the socio-economic structure of the population of Serbia and Montenegro with regard to elderly people in rural areas. IX International Scientific Symposium "Vlasinski susreti”:18.

7. Jelic $S$ (2003). Old people in the villages of the municipality of Pljevlja. IX International Scientific Symposium "Vlasinski susreti":31.

8. Kalezic Z (1997). Changes in the Montenegrin agriculture. Balkan village in the changes and the regional rural development. Proc The first international scientific symposium "Vlasinski susreti": 47-49.

9. Ministry of Economy of the Republic of Montenegro (2011). The regional development strategy of Montenegro for period 2010-2014. Podgorica.

10. Ploeg Van der, Douwe J (1994). Born from within: Practice and perspectives of endogenous rural development. Royal van Gorcum, Netherlands, $33 \mathrm{p}$.

11. Raonic S (2009). Durmitorsko područije i njegovo selo/ Durmitor area and its village. "Socioloska luca" journal III(1): 79-88.

12. Salvadori N (Ed) (2003). Old and new growth theories: An assessment. Edward Elgar Publishing Limited, UK-USA, 12 p.

13. Sarović R (2012a). Farmers migration in Montenegro. Sociology and Space. 194 (3):379-393.

14. Sarović R (2012b). Revitalizacija sela i orijentacije mladih $\mathrm{u}$ Crnoj Gori/Rural revitalization and orientation of young people in Montenegro (empirical study). "Socioloska luca" journal VI(1):39-47.

15. Statistical office of Montenegro-Monstat (2011). Census of Agriculture 2010. The structure of agricultural holdings, land and livestock resources, data by municipalities (I):48-58.

16. Statistical Office of Montenegro-Monstat (2011). Census of Agriculture 2010. The structure of agricultural holdings, land and livestock resources, data by municipalities (II):106-126.

17. Statistical Office of Montenegro-Monstat (2011). Census of the population, households and dwellings in Montenegro. Announcement number 83:5-7.

18. Statistical Office of Montenegro-Monstat (2012). Census data according to gender/sex. Announcement number 47:9-10.

19. Stojanov M (1997). Changes in the agriculture of Montenegro. Balkan village in the changes and the regional rural development. Proc The first international scientific symposium "Vlasinski susreti":18-26. 